\title{
Genetics of schizophrenia (Review)
}

\author{
SIMONA CORINA TRIFU ${ }^{1}$, BIANCA KOHN ${ }^{2}$, ANDREI VLASIE $^{2}$ and BOGDAN-EDUARD PATRICHI ${ }^{3}$ \\ ${ }^{1}$ Department of Neurosciences, 'Carol Davila' University of Medicine and Pharmacy, 020021 Bucharest; \\ ${ }^{2}$ Department of Psychiatry, 'Prof. Dr. Alexandru Obregia' Clinical Hospital of Psychiatry, 041914 Bucharest; \\ ${ }^{3}$ Department of Psychiatry and Psychology, 'Carol Davila' University of Medicine and Pharmacy, 020021 Bucharest, Romania
}

Received May 29, 2020; Accepted June 30, 2020

DOI: $10.3892 / \mathrm{etm} .2020 .8973$

\begin{abstract}
A comprehensive review of the body of genetic studies on schizophrenia seems even more daunting than the battle a psychiatrist wages daily in the office with her archenemy of a thousand faces. The following article reunites some genetic, epigenetic and environmental factors of schizophrenia from revered and vast studies in a chronological and progressive fashion. Twin studies set the basics of heritability and a particular study by Davis and Phelps considers the widely ignored influence of prenatal environment in the development of schizophrenia. Mostly ignited by linkage studies, candidate gene studies explore further by fine-mapping the hypothesized variants [mostly in the forms single nucleotide polymorphisms (SNPs) and less but with greater impact copy number variations (CNVs)] associated with the disease. Genome-wide association studies (GWAS) increase considerably the sample sizes and thus the validity of the results, while the next-generation sequencing (NGS) attain the highest yet unreplicated level of validity results.
\end{abstract}

\section{Contents}

1. Introduction

2. Heritability and twin-studies

3. Linkage studies

4. The search for candidate genes in schizophrenia

5. Genome-wide association studies: A quantum leap

6. Copy number variants: Rare but pivotal alleles

7. Next generation sequencing

8. Conclusions

Correspondence to: Dr Simona Corina Trifu, Department of Neurosciences, 'Carol Davila' University of Medicine and Pharmacy, 37 Dionisie Lupu Street, 020021 Bucharest, Romania

E-mail: simona.trifu@umfcd.ro

Key words: schizophrenia, gene expression, glutamatergic synapses, dopamine, twin studies

\section{Introduction}

Schizophrenia is a common yet devastating mental disorder characterized by a series of cognitive, behavioral and emotional dysfunctions, none of which are pathognomonic for the disease. It includes both positive symptoms, mainly represented by hallucinations and delusions and negative ones, such as blunted affect, avolition and social isolation, along with disturbed attention, executive function and working memory (1). Structural changes in the brain (white matter, grey matter, size) have been shown in controlled neuropathology leading to the idea that schizophrenia might be a true psychosomatic disorder (2). The onset is either abrupt or insidious, anywhere between late adolescence and mid of the 4th decade, followed by an episodic and deteriorating course, with every new episode worsening the prognosis $(3,4)$. Genetic epidemiological studies suggest that the life time risk of developing schizophrenia in general population is $0.5-1 \%$, although it increases considerably when relatives with the disorder are present (5). Even though the established genetic component of schizophrenia is high (heritability of $\sim 0.8$ ), much of its genetic architecture remains unknown (6). As many other complex psychiatric disorders, for example the intrapsychic dissociative phenomenon (also genetically conditioned) (7), schizophrenia is a multifactorial disorder, which encompasses the interplay of multiple susceptibility genes, epigenetic processes and environmental factors (8). Large studies on de novo, common and rare variants pointed to many causal aspects from the N-methyl-D-aspartate receptor signaling and postsynaptic density (PSD), calcium channels, targets of micro-RNA miR-137, glutamate pathways, processes related to neurogenesis and synaptic integrity and yet there are many unknown pathogenic pathways in the etiology of schizophrenia (9-13) as well as linking neuroendocrine aspects during pregnancy and postpartum life of the female patient affecting the new born development (14). We explored the contributions to the understanding of schizophrenia genetics of the classical twin and linkage studies, as well as the newer candidate gene and genome-wide association studies (GWAS), with the implied risk loci and single nucleotide polymorphism (SNP) and the critical, so-called copy number variation (CNV).

\section{Heritability and twin-studies}

Heritability is a concept that estimates in a population the fraction of differences within a trait that is due to genetic 
variability. It can vary from 0 to 1 , where 0 means no influence of genetic variation, while 1 shows $100 \%$ genetic contribution to the variation. Twin and adoption studies are the most frequently used study designs to portray heritability. The most cited study on heritability is the meta-analysis by Sullivan et al which includes 12 studies of European and Northern American origins and applies a multi-group twin model to conclude a heritability of up to $81 \%$ as well as clear evidence for shared environmental influences on schizophrenia (6).

An important discovery of family, twin and adoption studies is the proportional increase in risk for disease with the degree of genetic relationship to a person suffering from schizophrenia. Thus, the risk is approximated at $2 \%$ for third-degree relatives, $9 \%$ for first-degree relatives, $27 \%$ for children of two affected parents and $50 \%$ for monozygotic twins (15). As for an adopted child with a schizophrenic biological parent, the risk for disease proves to be 6 to 10 times higher than the general population (16). The nature of heredity in schizophrenia goes beyond the Mandelian rules and percentages of risk, in a complex landscape of different genetic polymorphisms with low penetrance and sometimes rare genetic variants of high risk (17).

The evidence that monozygotic (MZ) twins have high concordance of schizophrenia is taken as evidence for genetic influences in the majority of studies in this area (18). Moreover, a study by Waller et al (19) on monozygotic twins reared apart (MZA) concludes that sharing no environmental elements makes the MZA correlation a direct estimate of heritability. Still, a very important aspect is left out of all of the studies, that is, the prenatal environment in which the twins develop and the placentation variants, when considering placenta as the direct physical and psychological link between the mother and child, through which nutrients, drugs, toxins are shared and can affect the neurodevelopment of the embryos. In this case, a maternal infection with $\mathrm{MZ}$ twins will most likely affect both of them, while an infection of a DC twin mother is far more likely to pass to one but not the other.

A study by Davis and Phelps (18) tries to investigate this unaccounted for prenatal environment in twins, hypothesizing that monochorionic monozygotic (MC-MZ) twins are more concordant for schizophrenia than dichorionic monozygotic (DC-MZ) twins. Their hypothesis is in accord with the latest studies that show an increased risk of schizophrenia for children exposed to infectious disease especially in the second trimester (20-22). Because there are no studies investigating placentation in twins and the risk for schizophrenia, the authors used mirrored handedness as a retrospective marker for placentation. If placentation occurs within 4 days of fertilization, the twins will be DC-MZ, developing separate placentas and chorions and almost always separate circulations with the mother (23). However, if twining occurs after day 4, the twins will be MC-MZ and will share fetal circulation in $90 \%$ of cases. Twinning after day 4 will result in mirror imaging limited to the ectodermal layer and observed phenotypically as mirror hair swirls, dermal ridge patterns on hands and feet or hand preferences $(24,25)$. Only mirror hand preference was used as placentation marker in the study of 71 pairs of twins. The retrospective marker of mirror handedness for placentation has a few shortcomings that decrease its statistical power: handedness is a characteristic that could be caused by other factors than late twinning such as learning, brain pathology or perinatal stressors and $\mathrm{MC}$ twins with same-handedness could be considered DC twins with same handedness or vice versa confounding the study groups. Nevertheless, within the 71 case-study there were far more opposite-hand twin pairs that developed schizophrenia or psychosis ( 9 out of 15 pairs, 60\%) compared with the same hand preference group (18 out of 56, 32.1\%) (18). The low number of opposite-hand cases and the rate of $\mathrm{MC}$ twinning of generally $60 \%$ could mean that the opposite-hand group is in fact MC twins. Likewise, the relatively high concordance $(32.1 \%)$ for schizophrenia in the DC-MZ twins' group would imply that many of the second study group are MC-MZ same-handed twins (18). A way of validating these results would be a study with clear data for placentation, obtained post-partum; nonetheless, this study covers a mainly ignored possible source of schizophrenia in identical twins.

\section{Linkage studies}

Coupling studies was one of the first molecular genetic approaches. It resided in the notion that genetic traits located close to each other were more prone to be inherited together compared with traits farther apart (17). Although early linkage studies were inconsistent and hardly replicable, a large meta-analysis found a genome-wide result on $2 q$, fact confirmed partially five years later in another meta-analysis $(26,27)$.

A more recent and relevant large-scale linkage study has reignited the interest in the disrupted in schizophrenia 1 (DISC1) gene (associated with a large number of cytoskeletal proteins) resulted from a 1q42 translocation and previously described as segregating with psychopathology in a large Scottish family (28).

Other linkage studies using schizophrenia pedigrees of European and African American-decent has identified a larger region on $6 \mathrm{q}(6 \mathrm{q} 13-\mathrm{q} 26)$ as implicated in the disease (29). Also, G72 on chromosome 13q32-34, Epsin 4 on chromosome $5 q 33$ and other genes originally identified in linkage studies have follow up systematic association studies and fine-mapping of the regions (28).

\section{The search for candidate genes in schizophrenia}

Although gene identification represents an important step to uncovering the complex pathophysiology of schizophrenia, the road to the genetic origins of this disease is strewn with difficulties. It would have been ideal if the binary diagnosis ('affected'/'unaffected') employed in many genetic studies for schizophrenia were directly conclusive, but the vast phenotypic heterogeneity of the disease makes it difficult to account for the differences in representation throughout samples of various components of the illness. No single gene is necessary or sufficient to determine the disease, rather a combination of risk genes with small effects describe the highly heterogeneous genetic basis of schizophrenia (28). Other confounding variables of association studies of schizophrenia using the case-control design include small sample sizes (making the results possible false positive/ negative), the unequal representation of allele frequencies in the study groups or the publication bias that results in 
negative studies being rarely published in the journals where the original discovery was published (28-30). The discovery of susceptibility genes has been made successful as a result of the completion of sequencing the human genome. With the new DNA amplification methods, the huge number of genetic variants in schizophrenia is now easily processed in association studies (17). The most often studied variants are SNPs, that are substitutions of single bases within the genome. Methodologically, the allele frequencies of a group with a phenotype (e.g. schizophrenia) are compared with a control group (a population without the disease) (17). Another variation used in studies is CNV, which is characterized by duplications or deletions of DNA sequence. This variation is much less common than SNPs and because it affects a larger part of a chromosome the risk ration of disease is higher.

A review by Karayiogou and Gorgos (28) brings together a series of important candidate genes for schizophrenia, which were identified through systematic positional cloning in regions of linkage and linkage disequilibrium (LD) mapping methods. They have highlighted the consistent linkage signal of the chromosome 13q32-34 and also the implication of a broad region of the chromosome $8 \mathrm{p} 12-21$.

The gene for proline dehydrogenase maps on the $22 \mathrm{q} 11$ chromosome and association between hemizygous deletion of the 22q11 locus and schizophrenia has been previously stated (28). The gene codes for an enzyme that metabolizes L-proline, an amino acid that may be directly involved in glutamatergic transmission, one of the core pathways implicated in schizophrenia $(32,33)$. Through fine-mapping of the 22 q11 locus, overexpression of haplotypic variants at the $3^{\prime}$ end of the gene has been identified $(31,34)$. This finding has been confirmed in two independent studies evaluating a large (528) group of Chinese families, as well as 274 Ashkenazi Jewish origin families, even though a negative study was also published (35-37).

In another important study on 360 Iranian subjects (175 schizophrenic and 185 controls) 3 polymorphisms of the PRODH gene (757C/T, $1766 \mathrm{~A} / \mathrm{G}$ and $1852 \mathrm{G} / \mathrm{A})$ were associated with an increased risk of schizophrenia (38).

Rare variants of the gene have shown to reduce the activity of the enzyme (31). In an animal-model study on mice involving the PRODH gene variants, abnormal plasticity of glutamatergic synapses and dopamine dysregulation in the frontal cortex have been identified $(39,40)$. The dysregulation of dopamine generates increased levels of transcripts of the cathecol-O-methyltransferase (COMT) gene, also located on the $22 \mathrm{q} 11$ chromosome. This seems to be a triggered compensatory response to the glutamate dysregulation (28).

Another gene of the 22q11 locus is the ZDHHC8, identified in the same LD screen of the PRODH gene previously presented. Of the five SNPs identified, one of them (rs175174) was associated with a 1.5 -fold increase risk of the disease $(34,41)$.

Thirdly, the COMT gene is also located in 22q11 region, somewhere in between the 2 anterior genes described. Its codes for an enzyme involved in dopamine breakdown and a variant that modulates enzyme activity (Val, high activity; Met, low activity in the 158 codon) has been especially studied. The high activity (Val) allele appears to increase the risk of schizophrenia and affect executive function, a domain dysregulated in the disease, despite the unsubstantial results (42-45). On animal models, the low activity variant also proved to increase the risk for disease, the insufficient enzyme inappropriately metabolizing the increased dopamine (46). The result of the low activity enzyme was replicated in a follow-up study of children with 22 q11 microdeletion that showed decreased volume of the prefrontal cortex and levels of cognition, as well as the debut of psychotic episode in adolescence (47).

Dystrobrevin-binding protein 1 (DTNBP1) or dysbindin is another gene identified by fine-mapping of 6p24-22 locus, previously cited in linkage studies. Dysbindin is part of the dystrophin protein complex (DPC), as well as the biogenesis of lysosome-related organelle complex (BLOC) $(48,49)$. Two studies showcased the decrease of DTNBP1 mARN in the dorsolateral prefrontal cortex and hippocampus of schizophrenic patients compared with controls $(50,51)$.

The same approach of fine-mapping of 8p12-21 chromosome locus, previously identified in linkage studies has given the Neurolregulin 1 (NRG1) gene. Many differences in the frequency of haplotypes throughout the samples could indicate important heterogeneity of the LD structure of NRG1 locus or the coexistence of several alleles of risk there $(52,53)$. Because these haplotypes proved no functional relevance, the knockout NRG1 mice studied cannot be used to model the implication of the gene in determining schizophrenia $(54,55)$.

The follow-up systematic association studies for the disrupted in schizophrenia 1 (DISC1) gene identified in linkage studies, identified a positional candidate on 1q42. Even tough negative studies were reported, the gene showed association with schizophrenia for allelic heterogeneity (56-58). The complexity of the gene is supported by different studies showing variants of the gene involved in altered hippocampal structure and functions in healthy individuals or visual working memory performance $(59,60)$. Furthermore, the gene has unclear implications in development and plasticity, being involved in a series of cellular functions such as cell migration, microtubule function, membrane trafficking of receptors, neurite outgrowth, mitochondrial function and phosphodiesterase signaling (61).

Also mentioned in the linkage studies chapter is the trace amine receptor 4 (TAAR6) gene that was subsequently fine-mapped and identified as a positional candidate for schizophrenia on the $6 \mathrm{q} 23.2$ (62). It is considered a GPCR extensively expressed in the brain (63).

Another solid linkage signal for both bipolar disorder and schizophrenia has led to the fine-mapping of the 13q32-34 locus. The results included several SNPs and haplotypes of the locus associated with schizophrenia in French-Canadian studies and replicated in Russian ones (60). Through enzymatic studies it was shown that G72 modulates the activity of D-amino acid oxidase (DAAO) and in turn affects glutamatergic signaling (64).

Similar implication in both schizophrenia and bipolar disorder were suggested for the abnormal expression of the carboxyl-terminal PDZ ligand of neuronal nitric oxide synthase (CAPON) gene (65). CAPON was also shown to be involved in NMDA receptor-coupled nitric oxide signaling (66).

Located on chromosome 5q33, Epsin 4 gene was fine-mapped and 4 haplotypes showed evidence of LD with 
schizophrenia (67). The gene codes for a protein involved in the transport and stability of neurotransmitter vesicles at synapses.

Finally, the GABA subunit gene cluster showed in sequential studies evidence for the implication of GABA transmission in schizophrenia (68).

To complement these findings, a separate meta-analysis identified other associated genes at the dopaminergic (DRD2, DRD3 and DRD4) and serotoninergic (HTR2A, SLC6A4 and TPH1) systems, as well as genes affecting neuro development (AHI1, MTHFR, RELN and TRKA) (69).

Aside from the described candidate genes, another 12 regions (2p, 5q, 3p, 11q, 2q, 1q, 22q, 8p, 6p, 20p, 13q and $14 q)$ of the human genome were identified to likely contain susceptibility gene for schizophrenia $(69,70)$.

Taking the research results to the next level would mean to identify and characterize the susceptibility genes for schizophrenia in vivo, allowing for development of mechanism-targeted therapies.

\section{Genome-wide association studies: A quantum leap}

The leap in GWAS studies consists in the number of SNPs tested, which could go up to 10 million in a single experiment compared with only a few SNPs analyzed in candidate gene studies (17). This significant quantitative improvement raises the significance threshold, reducing the chance of false-positives.

Chronologically, in the first major genome-wide study by O'Donovan et al a polymorphism in the zinc finger protein 804 A (ZNF804) gene was associated with schizophrenia (71). The next important study by Stefansson et al (72) brought about associations in the transcription factor 4 (TCF) gene, Neurogranin (NRGRN) gene and the MHC region, the last association being convincingly replicated in large consortia (72-74).

Psychiatric Genome Wide Association Study Consortium (PGC) represents the joint forces of many specialists world-wide and was created out of the need for greater samples, reaching the level of thousands (11). The latest and most impressing study of the Consortium resulted in 128 associations or 108 independent loci with genome-wide relevance, obtained on a remarkable sample of 36,989 patients and 113,075 controls (75).

However, impressing the results of GWAS studies compared with those of the previous era, the case control numbers remain too low to encircle the entire amount of genetic variability that accounts for susceptibility to schizophrenia.

\section{Copy number variants: Rare but pivotal alleles}

The possibility of assessing millions of SNPs at once introduced by GWAS generated enthusiasm of resolving the genetic basis of schizophrenia. Although considerable genome wide meta-analyses have singled-out many promising candidate genes, they only account for $\sim 2$ of $80 \%$ heritability in schizophrenia (76,77).

With increasing evidence showing that common variants cover a tiny fraction of heritability, the possible implication of rare variants (both SNPs and CNVs) becomes higher. Moreover, rare de novo CNVs with high penetrance could account for an important piece of the heritability puzzle (78).
By definition, CNVs are structural genomic variants that comprise of duplications, deletions, insertions and translocations of varying sizes from 1 kilobase to several megabase pairs (79). A well-known CNV is the 22q11 deletion, 20-30\% of people with it having schizophrenia (80). Concomitantly, the 22 q11.2 deletion causes the velocardiofacial syndrome (Di George syndrome), a multiphenotypical severe disorder (81).

In a study by Luo et al employing integration of prioritization data with genetic association and PPI interaction (protein-protein interaction) the following 8 genes were identified to be frequently disrupted by CNVs in schizophrenia cases: NRXN1, CHRNA7, BCL9, CYFIP1, GJA8, NDEI, SNAP29 and GJA5 (79).

\section{Next generation sequencing}

New advances in sequencing technologies come in the form of cost-effective 'whole genome sequencing' and 'well exome sequencing'. An initial pilot study applying NGS to a trio generated intriguing, yet unsustain results that await to be confirmed (82).

Three other larger studies lead the way in the NGS era. In a study by Gulsuner et al (13) genes involved in the fetal prefrontal cortex neurogenesis were identified after the exome sequencing of 105 patients with schizophrenia, 84 unaffected siblings and 210 unaffected parents. Fromer et al (83), aside from reinstating the genetic overlap of schizophrenia and neurodevelopmental disorders (autism and mental retardation), also signaled the presence of de novo CNVs in the activity-regulated cytoskeleton-associated protein (ARC) or $\mathrm{N}$-methyl-D-aspartate receptor complex (NMDAR). Lastly, Purcell et al (84) confirmed the presence of CNVs in ARC and NMDAR complex as well as in Fragile-X-mental retardation-protein-protein complex (FMRP) and calcium channel complexes.

\section{Conclusions}

The level and scale of testing the genetic fabric of schizophrenia has come a long way from the first twin-pair studies to the meta-analyses of GWAS involving simultaneous testing of millions of SNPs from thousands of subjects or 'the whole genome sequencing' applied in trios or case-controls, courtesy of the NGS. This urge for covering exponentially more genome at once, illustrated even by the creation of Psychiatric Genome Wide Association Study Consortium (PGC) highlights once for all the enormous genetic heterogeneity and still unchartered interdependences of genes in schizophrenia. From the impressing $80 \%$ heritability stated by Sullivan, very little has been pinpointed and confirmed in live models or come even close to the ultimate goal of targeted therapy. The closest to this much desired goal are maybe the prioritized CNVs of genes like NRXN1, CHRNA7, BCL9 or CYFIP1. Many confounding variables still plague all levels of testing starting from sample sizes, absence of negative studies of insufficient follow-up for high credibility.

\section{Acknowledgements}

Not applicable. 


\section{Funding}

No funding was received.

\section{Availability of data and materials}

Not applicable.

\section{Authors' contributions}

SCT contributed in all the stages of the article preparation, designed the study and revised the manuscript for important intellectual content. BK and AV acquired the data by screening the studies identified on PubMed and drafted the manuscript. BEP contributed to the conception of the study and revised the manuscript. All authors read and approved the final manuscript.

\section{Ethics approval and consent to participate}

Not applicable.

\section{Patient consent for publication}

Not applicable.

\section{Competing interests}

The authors declare that they have no competing interests.

\section{References}

1. American Psychiatric Association: Schizophrenia Spectrum and Other Psychotic Disorders In Diagnostic and statistical manual of mental disorders. 5th edition. Washington, DC, 2013.

2. Trifu S, Delcuescu C and Boer CM: Psychosomatics and psychical tension (clinical research). Procedia Soc Behav Sci 33: 128-132, 2012.

3. Lieberman JA, Perkins D, Belger A, Chakos M, Jarskog F, Boteva $\mathrm{K}$ and Gilmore $\mathrm{J}$ : The early stages of schizophrenia: Speculations on pathogenesis, pathophysiology, and therapeutic approaches. Biol Psychiatry 50: 884-897, 2001.

4. Perkins DO, Gu H, Boteva K and Lieberman JA: Relationship between duration of untreated psychosis and outcome in first-episode schizophrenia: A critical review and meta-analysis. Am J Psychiatry 162: 1785-1804, 2005.

5. Saha S, Chant D, Welham J and McGrath J: A systematic review of the prevalence of schizophrenia. PLoS Med 2: e141, 2005.

6. Sullivan PF, Kendler KS and Neale MC: Schizophrenia as a complex trait: Evidence from a meta-analysis of twin studies. Arch Gen Psychiatry 60: 1187-1192, 2003.

7. Trifu S: Dissociative Identity Disorder. Psychotic functioning and impairment of growing-up processes. J Educ Sci Psychol 9 102-108, 2019.

8. Karayiorgou M and Gogos JA: A turning point in schizophrenia genetics. Neuron 19: 967-979, 1997.

9. Kirov G, Pocklington AJ, Holmans P, Ivanov D, Ikeda M, Ruderfer D, Moran J, Chambert K, Toncheva D, Georgieva L, et al: De novo CNV analysis implicates specific abnormalities of postsynaptic signalling complexes in the pathogenesis of schizophrenia. Mol Psychiatry 17: 142-153, 2012.

10. Ripke S, O'Dushlaine C, Chambert K, Moran JL, Kähler AK, Akterin S, Bergen SE, Collins AL, Crowley JJ, Fromer M, et al; Multicenter Genetic Studies of Schizophrenia Consortium; Psychosis endophenotypes international consortium; Wellcome trust case control consortium 2: Genome-wide association analysis identifies 13 new risk loci for schizophrenia. Nat Genet 45: 1150-1159, 2013

11. Schizophrenia Psychiatric Genome-Wide Association Study (GWAS) Consortium: Genome-wide association study identifies five new schizophrenia loci. Nat Genet 43: 969-976, 2011.
12. Walsh T, McClellan JM, McCarthy SE, Addington AM, Pierce SB, Cooper GM, Nord AS, Kusenda M, Malhotra D, Bhandari A, et al: Rare structural variants disrupt multiple genes in neurodevelopmental pathways in schizophrenia. Science 320: 539-543, 2008.

13. Gulsuner S, Walsh T, Watts AC,Lee MK, Thornton AM, Casadei S, Rippey C, Shahin H, Nimgaonkar VL, Go RC, et al; Consortium on the Genetics of Schizophrenia (COGS); PAARTNERS Study Group: Spatial and temporal mapping of de novo mutations in schizophrenia to a fetal prefrontal cortical network. Cell 154: 518-529, 2013.

14. Trifu S, Vladuti A and Popescu A: Neuroendocrine aspects of pregnancy and postpartum depression. Acta Endocrinol (Bucur) 15: 410-415, 2019.

15. Ng MY, Levinson DF, Faraone SV, Suarez BK, DeLisi LE, Arinami T, Riley B, Paunio T, Pulver AE, Irmansyah, et al: Meta-analysis of 32 genome-wide linkage studies of schizophrenia. Mol Psychiatry 14: 774-785, 2009.

16. Shih RA, Belmonte PL and Zandi PP: A review of the evidence from family, twin and adoption studies for a genetic contribution to adult psychiatric disorders. Int Rev Psychiatry 16: 260-283, 2004.

17. Rujescu D: Search for risk genes in schizophrenia. Nervenarzt 88: 751-754, 2017.

18. Davis JO and Phelps JA: Twins with schizophrenia: Genes or germs? Schizophr Bull 21: 13-18, 1995.

19. Waller NG, Kojetin BA, Bouchard TJ Jr, Lykken DT and Tellegen A: Genetic and environmental influences on religious interests, attitudes, and values: A study of twins reared apart and together. Psychol Sci 1: 138-142, 1990.

20. Torrey EF, Bowler AE, Taylor EH and Gottesman II: Schizophrenia and Manic Depression Disorder: The Biological Roots of Mental Illness as Revealed by the Landmark Study of Identical Twins. Basic Books, New York, NY, p274, 1994.

21. Bracha HS, Torrey EF, Gottesman II, Bigelow LB and Cuniff C: Second trimester markers of fetal size in schizophrenia: A study of monozygotic twins. Am J Hum Genet 28: 433-441, 1976.

22. Pulver AE, Liang KY, Brown CH, Wolyniec P, McGrath J, Adler L, Tam D, Carpenter WT Jr and Childs B: Risk factors in schizophrenia. Season of birth, gender, and familial risk. Br J Psychiatry 160: 65-71, 1992.

23. Bulmer M (ed): The Biology of Twinning in Man. Clarendon Press, Oxford, p205, 1970.

24. Macgillivray I, Nylander P and Corney G (eds): Mythology and customs associated with twins. In: Human Multiple Reproduction. WB Saunders Company, London, 1975.

25. Springer SP and Deutsch G: Left Brain, Right Brain. Freeman \& Company, San Francisco, CA, p243, 1981.

26. Greenwood TA, Swerdlow NR, Gur RE, Cadenhead KS, Calkins ME, Dobie DJ, Freedman R, Green MF, Gur RC, Lazzeroni LC, et al: Genome-wide linkage analyses of 12 endophenotypes for schizophrenia from the Consortium on the Genetics of Schizophrenia. Am J Psychiatry 170: 521-532, 2013.

27. Vieland VJ, Walters KA, Lehner T, Azaro M, Tobin K, Huang Y and Brzustowicz LM: Revisiting schizophrenia linkage data in the NIMH Repository: Reanalysis of regularized data across multiple studies. Am J Psychiatry 171: 350-359, 2014.

28. Karayiorgou M and Gogos JA: Schizophrenia genetics: Uncovering positional candidate genes. Eur J Hum Genet 14: $512-519,2006$.

29. Levinson DF, Holmans P, Straub RE, Owen MJ, Wildenauer DB, Gejman PV, Pulver AE, Laurent C, Kendler KS, Walsh D, et al: Multicenter linkage study of schizophrenia candidate regions on chromosomes 5q, 6q, 10p, and 13q: Schizophrenia linkage collaborative group III. Am J Hum Genet 67: 652-663, 2000.

30. Campbell CD, Ogburn EL, Lunetta KL, Lyon HN, Freedman ML, Groop LC, Altshuler D, Ardlie KG and Hirschhorn JN: Demonstrating stratification in a European American population. Nat Genet 37: 868-872, 2005.

31. Liu H, Heath SC, Sobin C, Roos JL, Galke BL, Blundell ML, Lenane M, Robertson B, Wijsman EM, Rapoport JL, et al: Genetic variation at the 22q11 PRODH2/DGCR6 locus presents an unusual pattern and increases susceptibility to schizophrenia. Proc Natl Acad Sci USA 99: 3717-3722, 2002.

32. Renick SE, Kleven DT, Chan J, Stenius K, Milner TA, Pickel VM and Fremeau RT Jr: The mammalian brain high-affinity L-proline transporter is enriched preferentially in synaptic vesicles in a subpopulation of excitatory nerve terminals in rat forebrain. J Neurosci 19: 21-33, 1999.

33. Trifu S: Neuroendocrine insights into burnout syndrome. Acta Endocrinol (Bucur) 15: 404-405, 2019. 
34. Liu H, Abecasis GR, Heath SC, Knowles A, Demars S, Chen YJ, Roos JL, Rapoport JL, Gogos JA and Karayiorgou M: Genetic variation in the 22q11 locus and susceptibility to schizophrenia. Proc Natl Acad Sci USA 99: 16859-16864, 2002

35. Li T, Ma X, Sham PC, Sun X, Hu X, Wang Q, Meng H, Deng W, Liu X, Murray RM, et al: Evidence for association between novel polymorphisms in the PRODH gene and schizophrenia in a Chinese population. Am J Med Genet B Neuropsychiatr Genet 129B: 13-15, 2004

36. Fallin MD, Lasseter VK, Avramopoulos D, Nicodemus KK, Wolyniec PS, McGrath JA, Steel G, Nestadt G, Liang KY, Huganir RL, et al: Bipolar I disorder and schizophrenia: A 440 -single-nucleotide polymorphism screen of 64 candidate genes among Ashkenazi Jewish case-parent trios. Am J Hum Genet 77: 918-936, 2005

37. Williams HJ, Williams N, Spurlock G, Norton N, Ivanov D, McCreadie RG, Preece A, Sharkey V, Jones S, Zammit S, et al: Association between PRODH and schizophrenia is not confirmed. Mol Psychiatry 8: 644-645, 2003.

38. Ghasemvand F, Omidinia E, Salehi $\mathrm{Z}$ and Rahmanzadeh $\mathrm{S}$ : Relationship between polymorphisms in the proline dehydrogenase gene and schizophrenia risk. Genet Mol Res 14: 11681-11691, 2015

39. Gogos JA, Santha M, Takacs Z, Beck KD, Luine V, Lucas LR, Nadler JV and Karayiorgou M: The gene encoding proline dehydrogenase modulates sensorimotor gating in mice. Nat Genet 21 434-439, 1999

40. Paterlini M, Zakharenko SS, Lai WS, Qin J, Zhang H, Mukai J, Westphal KG,Olivier B, Sulzer D, Pavlidis P, et al: Transcriptional and behavioral interaction between 22q11.2 orthologs modulates schizophrenia-related phenotypes in mice. Nat Neurosci 8 : 1586-1594, 2005.

41. Mukai J, Liu H, Burt RA, Swor DE, Lai WS, Karayiorgou M and Gogos JA: Evidence that the gene encoding ZDHHC8 contributes to the risk of schizophrenia. Nat Genet 36: 725-731, 2004

42. Shifman S, Bronstein M, Sternfeld M, Pisanté-Shalom A, Lev-Lehman E, Weizman A, Reznik I, Spivak B, Grisaru N Karp L, et al: A highly significant association between a COMT haplotype and schizophrenia. Am J Hum Genet 71: 1296-1302, 2002.

43. Tsai SJ, Hong CJ, Hou SJ and Yen FC: Lack of association of catechol-O-methyltransferase gene Val108/158Met polymorphism with schizophrenia: A family-based association study in a Chinese population. Mol Psychiatry 11: 2-3, 2006.

44. Egan MF, Goldberg TE, Kolachana BS, Callicott JH, Mazzanti CM, Straub RE, Goldman D and Weinberger DR: Effect of COMT Val108/158 Met genotype on frontal lobe function and risk for schizophrenia. Proc Natl Acad Sci USA 98: 6917-6922, 2001.

45. Ho BC, Wassink TH, O'Leary DS, Sheffield VC and Andreasen NC: Catechol-O-methyl transferase Val158Met gene polymorphism in schizophrenia: Working memory, frontal lobe MRI morphology and frontal cerebral blood flow. Mol Psychiatry 10: 229, 287-298, 2005.

46. Williams HJ, Owen MJ and O'Donovan MC: Is COMT a susceptibility gene for schizophrenia? Schizophr Bull 33: 635-641, 2007.

47. Gothelf D, Eliez S, Thompson T, Hinard C, Penniman L, Feinstein C, Kwon H, Jin S, Jo B, Antonarakis SE, et al: COMT genotype predicts longitudinal cognitive decline and psychosis in 22q11.2 deletion syndrome. Nat Neurosci 8: 1500-1502, 2005.

48. Benson MA, Newey SE, Martin-Rendon E, Hawkes R and Blake DJ: Dysbindin, a novel coiled-coil-containing protein that interacts with the dystrobrevins in muscle and brain. J Biol Chem 276: 24232-24241, 2001.

49. Li W, Zhang Q, Oiso N, Novak EK, Gautam R, O'Brien EP, Tinsley CL, Blake DJ, Spritz RA, Copeland NG, et al: Hermansky-Pudlak syndrome type 7 (HPS-7) results from mutant dysbindin, a member of the biogenesis of lysosome-related organelles complex 1 (BLOC-1). Nat Genet 35: 84-89, 2003.

50. Talbot K, Eidem WL, Tinsley CL, Benson MA, Thompson EW, Smith RJ, Hahn CG, Siegel SJ, Trojanowski JQ, Gur RE, et al Dysbindin-1 is reduced in intrinsic, glutamatergic terminals of the hippocampal formation in schizophrenia. J Clin Invest 113: 1353-1363, 2004

51. Weickert CS, Straub RE, McClintock BW, Matsumoto M, Hashimoto R, Hyde TM, Herman MM, Weinberger DR and Kleinman JE: Human dysbindin (DTNBP1) gene expression in normal brain and in schizophrenic prefrontal cortex and midbrain. Arch Gen Psychiatry 61: 544-555, 2004.
52. Li T, Stefansson H, Gudfinnsson E, Cai G, Liu X, Murray RM, Steinthorsdottir V, Januel D, Gudnadottir VG, Petursson H, et al: Identification of a novel neuregulin 1 at-risk haplotype in Han schizophrenia Chinese patients, but no association with the Icelandic/Scottish risk haplotype. Mol Psychiatry 9: 698-704, 2004.

53. Zhao X, Shi Y, Tang J, Tang R, Yu L, Gu N, Feng G, Zhu S, Liu H, Xing Y, et al: A case control and family based association study of the neuregulin1 gene and schizophrenia. J Med Genet 41: 31-34, 2004.

54. Rimer M, Barrett DW, Maldonado MA, Vock VM and Gonzalez-Lima F: Neuregulin-1 immunoglobulin-like domain mutant mice: Clozapine sensitivity and impaired latent inhibition. Neuroreport 16: 271-275, 2005.

55. Yang X, Kuo Y, Devay P, Yu C and Role L: A cysteine-rich isoform of neuregulin controls the level of expression of neuronal nicotinic receptor channels during synaptogenesis. Neuron 20 : 255-270, 1998 .

56. Falola O, Osamor VC, Adebiyi M and Adebiyi E: Analyzing a single nucleotide polymorphism in schizophrenia: A meta-analysis approach. Neuropsychiatr Dis Treat 13: 2243-2250, 2017

57. Hennah W, Varilo T, Kestilä M, Paunio T, Arajärvi R, Haukka J, Parker A, Martin R, Levitzky S, Partonen T, et al: Haplotype transmission analysis provides evidence of association for DISC1 to schizophrenia and suggests sex-dependent effects. Hum Mol Genet 12: 3151-3159, 2003.

58. Hodgkinson CA, Goldman D, Jaeger J, Persaud S, Kane JM, Lipsky RH and Malhotra AK: Disrupted in schizophrenia 1(DISC1): Association with schizophrenia, schizoaffective disorder, and bipolar disorder. Am J Hum Genet 75: 862-872, 2004.

59. Callicott JH, Straub RE, Pezawas L, Egan MF, Mattay VS, Hariri AR, Verchinski BA, Meyer-Lindenberg A, Balkissoon R, Kolachana B, et al: Variation in DISC1 affects hippocampal structure and function and increases risk for schizophrenia. Proc Natl Acad Sci USA 102: 8627-8632, 2005

60. Hennah W, Tuulio-Henriksson A, Paunio T, Ekelund J, Varilo T, Partonen T, Cannon TD, Lönnqvist J and Peltonen L: A haplotype within the DISC1 gene is associated with visual memory functions in families with a high density of schizophrenia. Mol Psychiatry 10: 1097-1103, 2005.

61. Sawa A and Snyder SH: Genetics. Two genes link two distinct psychoses. Science 310: 1128-1129, 2005.

62. el-Husseini AD and Bredt DS: Protein palmitoylation: A regulator of neuronal development and function. Nat Rev Neurosci 3: 791-802, 2002.

63. Borowsky B, Adham N, Jones KA, Raddatz R, Artymyshyn R, Ogozalek KL, Durkin MM, Lakhlani PP, Bonini JA, Pathirana S, et al: Trace amines: Identification of a family of mammalian $\mathrm{G}$ protein-coupled receptors. Proc Natl Acad Sci USA 98: 8966-8971, 2001

64. Chumakov I, Blumenfeld M, Guerassimenko O, Cavarec L, Palicio M, Abderrahim H, Bougueleret L, Barry C, Tanaka H, La Rosa P, et al: Genetic and physiological data implicating the new human gene G72 and the gene for D-amino acid oxidase in schizophrenia. Proc Natl Acad Sci USA 99: 13675-13680, 2002.

65. Mulle JG, Chowdari KV, Nimgaonkar V and Chakravarti A: No evidence for association to the G72/G30 locus in an independent sample of schizophrenia families. Mol Psychiatry 10: 431-433, 2005.

66. Jaffrey SR, Snowman AM, Eliasson MJ, Cohen NA and Snyder SH: CAPON: A protein associated with neuronal nitric oxide synthase that regulates its interactions with PSD95. Neuron 20: 115-124, 1998.

67. Pimm J, McQuillin A, Thirumalai S, Lawrence J, Quested D, Bass N, Lamb G, Moorey H, Datta SR, Kalsi G, et al: The Epsin 4 gene on chromosome 5q, which encodes the clathrin-associated protein enthoprotin, is involved in the genetic susceptibility to schizophrenia. Am J Hum Genet 76: 902-907, 2005.

68. Lewis DA, Hashimoto T and Volk DW: Cortical inhibitory neurons and schizophrenia. Nat Rev Neurosci 6: 312-324, 2005.

69. Badner JA and Gershon ES: Meta-analysis of whole-genome linkage scans of bipolar disorder and schizophrenia. Mol Psychiatry 7: 405-411, 2002.

70. Lewis CM, Levinson DF, Wise LH, DeLisi LE, Straub RE, Hovatta I, Williams NM, Schwab SG, Pulver AE, Faraone SV, et al: Genome scan meta-analysis of schizophrenia and bipolar disorder, part II: Schizophrenia. Am J Hum Genet 73: 34-48, 2003.

71. O'Donovan MC, Craddock N, Norton N, Williams H, Peirce T, Moskvina V, Nikolov I, Hamshere M, Carroll L, Georgieva L, et al; Molecular genetics of schizophrenia collaboration: Identification of loci associated with schizophrenia by genome-wide association and follow-up. Nat Genet 40: 1053-1055, 2008. 
72. Stefansson H, Ophoff RA, Steinberg S, Andreassen OA, Cichon S, Rujescu D, Werge T, Pietiläinen OP, Mors O, Mortensen PB, et al; Genetic Risk and Outcome in Psychosis (GROUP): Common variants conferring risk of schizophrenia. Nature 460: 744-747, 2009.

73. Purcell SM, Wray NR, Stone JL, Visscher PM, O'Donovan MC, Sullivan PF and Sklar P; International Schizophrenia Consortium: Common polygenic variation contributes to risk of schizophrenia and bipolar disorder. Nature 460: 748-752, 2009.

74. Richards AL, Pardiñas AF, Frizzati A, Tansey KE, Lynham AJ, Holmans P, Legge SE, Savage JE, Agartz I, Andreassen OA, et al; GROUP Investigators; EUGEI WP2 Group; Schizophrenia Working Group of the Psychiatric Genomics Consortium: The relationship between polygenic risk scores and cognition in schizophrenia. Schizophr Bull 46: 336-344, 2020.

75. Schizophrenia Working Group of the Psychiatric Genomics Consortium: Biological insights from 108 schizophrenia-associated genetic loci. Nature 511: 421-427, 2014.

76. Gatt JM, Burton KL, Williams LM and Schofield PR: Specific and common genes implicated across major mental disorders: A review of meta-analysis studies. J Psychiatr Res 60: 1-13, 2015.

77. Crow TJ: 'The missing genes: What happened to the heritability of psychiatric disorders?'. Mol Psychiatry 16: 362-364, 2011.

78. McClellan JM, Susser Eand King MC: Schizophrenia: A common disease caused by multiple rare alleles. Br J Psychiatry 190 194-199, 2007.
79. Luo X, Huang L, Han L, Luo Z, Hu F, Tieu R and Gan L: Systematic prioritization and integrative analysis of copy number variations in schizophrenia reveal key schizophrenia susceptibility genes. Schizophr Bull 40: 1285-1299, 2014.

80. Murphy KC, Jones LA and Owen MJ: High rates of schizophrenia in adults with velo-cardio-facial syndrome. Arch Gen Psychiatry 56: 940-945, 1999.

81. Kobrynski LJ and Sullivan KE: Velocardiofacial syndrome, DiGeorge syndrome: The chromosome 22q11.2 deletion syndromes. Lancet 370: 1443-1452, 2007.

82. Giegling I, Hosak L, Mössner R, Serretti A, Bellivier F, Claes S, Collier DA, Corrales A, DeLisi LE, Gallo C, et al: Genetics of schizophrenia: A consensus paper of the WFSBP Task Force on Genetics. World J Biol Psychiatry 18: 492-505, 2017.

83. Fromer M, Pocklington AJ, Kavanagh DH, Williams HJ, Dwyer S, Gormley P, Georgieva L, Rees E, Palta P, Ruderfer DM, et al: De novo mutations in schizophrenia implicate synaptic networks. Nature 506: 179-184, 2014.

84. Purcell SM, Moran JL, Fromer M, Ruderfer D, Solovieff N, Roussos P, O'Dushlaine C, Chambert K, Bergen SE, Kähler A, et al: A polygenic burden of rare disruptive mutations in schizophrenia. Nature 506: 185-190, 2014.

This work is licensed under a Creative Commons Attribution-NonCommercial-NoDerivatives 4.0 International (CC BY-NC-ND 4.0) License. 